\title{
CHARACTERISTICS OF ACHENES IN POTENTILLA COLLINA GROUP (ROSACEAE)
}

\author{
JEREMI KOŁODZIEJEK ${ }^{1}$, BARBARA GABARA ${ }^{2}$ \\ ${ }^{1}$ Department of Geobotany and Plant Ecology \\ University of Łódź \\ e-mail: kolo@biol.uni.lodz.pl \\ 2 Department of Plant Cytology and Cytochemistry \\ University of Łódź \\ Banacha 12/16, 90-237 Łódź, Poland
}

(Received: April 10, 2006. Accepted: October 10, 2006)

\begin{abstract}
Achenes morphology in taxa from Potentilla collina s.l. i.e. P. collina Wibel s.s., P. leucopolitana P.J. Müller, $P$. thyrsiflora Hülsen ex Zimmet. $P$. thyrsiflora var. isosepala Th. W., P. silesiaca Uechtr. And $P$. wimanniana Günther \& Schummel was examined with stereoscope and scanning electron microscopy. Achenes of these taxa varied slightly in shape, size and colour, while marked differences among them appeared in the surface sculpture and in the dimensions of aril, dorsal ridge and ribs. SEM analyses allowed to distinguish two distinct morphological types of achenes. Type I - with ruminate sculpture and aggregates of some material, various in shape and size, at the surface of partly destroyed epidermal cells covering fruit wall in $P$. leucopolitana, $P$. wimanniana and $P$. thyrsiflora. Type II - with ruminate-reticulate sculpture due to well preserved epidermal cells in $P$ collina, $P$. silesiaca and $P$. thyrsiflora var. isosepala. The obtained results have supported Błocki's suggestion to treat $P$. thyrsiflora var. isosepala as a separate species named $P$. isosepala. However, similarities in the surface sculpture of achenes in some taxa of $P$. collina group did not facilitate their classification, therefore this feature may be a valuable taxonomical criterium only in combination with others.
\end{abstract}

KEY WORDS: achenes, fruit wall sculpture, SEM, Potentilla collina group, taxonomy.

\section{INTRODUCTION}

The Potentilla collina group (Rosaceae), due to its changeability and related to it diversity of forms, belongs to the "critical" plant taxa. The causes of this changeability are the occurrence of polyploids, easiness of developing interspecies hybrids and ability to reproduce both sexually and apomictically, in the form of facultative apomixis (Müntzing 1928, 1931, 1958; Asker and Fröst 1970; Asker 1966, 1970, 1985, 1986; Eriksson et al 1998; Gregor et al. 2003). Hence, the division of this species aggregate in an intermediate one between taxa of the sections Argenteae $(P$. argentea group and $P$. inclinata) and Aureae (most propably $P$. tabernaemontani and $P$. incana), according to exclusively morphological criteria is complicated (Wolf 1908; Szafer and Pawłowski 1955; Gerstberger 2002; Kurtto et al. 2004). Differences between apomictic microspecies (agamic species) are most frequently slight, but usually stable. Because agamic taxa are more stable than microspecies of selffertilizing taxa, there is a temptation to ascri- be the rank of taxonomic species to apomictic microspecies (Stace 1989).

In Poland between 5 and 8 species of the Potentilla collina group have been identified i.e. $P$. collina Wibel, $P$. isosepala Błocki, P. leucopolitana P.J. Müll., P. silesiaca Uechtr., $P$. sordida Zimmet., $P$. thyrsiflora Zimmet., $P$. wimanniana Günth. et Schumm and $P$. wimannioides (Szafer and Pawłowski 1955; Zając and Zając 2001; Mirek et al. 2002). They were classified as microspecies, subspecies or rarely varieties (Ascherson and Graebner 1904-1905; Wolf 1908; Szafer and Pawłowski 1955; Gerstberger 2002; Kurtto et al. 2004).

Identification of most of the taxa from Potentilla collina group is based on the length ratio of sepals to corolla petals, the shape of carpel style, the number of leaflets on basal leaves, the pattern of pubescence of upper and lower surfaces of leaf blades (Wolf 1901, 1903, 1908; Juzepczuk 1941; Ball et al. 1968; Borhidi and Isépy 1965; Soják 1995), as well as on the type of trichomes and the anatomy of leaves (Kołodziejek and Gabara 2003). 
It is known that fruit and seeds are very useful in identification and classification of plant taxa (Karcz 1996; Liu and Lin 1999; Özcan 2004; Maciejewska-Rutkowska and Bednarz 2004; Fagúndez and Izco 2004). Description of achenes from taxa of $P$. collina group is limited to their length, shape and colour (Wolf 1908; Juzepczuk 1941; Kelley 1953; Szafer and Pawłowski 1955; Soják 1995). These features, however, are not sufficient to identify the particular taxa.

Fruit in Potentilla named also achene is dry, not dehiscent and monospermous, small in size and brown in colour (Wolf 1908; Juzepczuk 1941; Kelley 1953; Szafer and Pawłowski 1955; Ball et al. 1968; Leht 1990; Andenberg 1994; Soják 1995; Gerstberger 2002). This latter feature is a good criterion of its maturity, since an unripe fruit is more light brown than a mature one.

Therefore, the purpose of the present paper was the complex morphometric analysis of the achenes from 6 taxa of $P$. collina group together with their shape, colour and surface sculpture.

\section{MATERIAL AND METHODS}

The following taxa from $P$. collina s.l. i.e. $P$. collina s.s., $P$. leucopolitana, $P$. thyrsiflora, $P$. thyrsiflora var. isosepa$l a, P$. wimanniana and $P$. silesiaca were analysed. The nomenclature of taxa was used according to Wolf (1908) and Kurtto et al. (2004). Plant material originated from natural habitat in Poland except $P$. silesiaca and $P$. thyrsiflora var. isosepala which came from herbaria (LE and BP).

Only mature, fully developed achenes, intensively brown in colour were used in the investigations while distinctly smaller and deformed ones were discarded.

Colour of the achenes was determined in day light on the basis of colour scale recommended by Berggren (1969). Dimensions - length, width and thickness of the achenes, width of the aril, width and thickness of the ribs and width and height of dorsal ridge were measured according to the description presented in Figure 1. Morphometric analysis of the achenes except, aril and rib dimensions, was made using a stereoscope microscope Nikon SMZ 800 with mil-

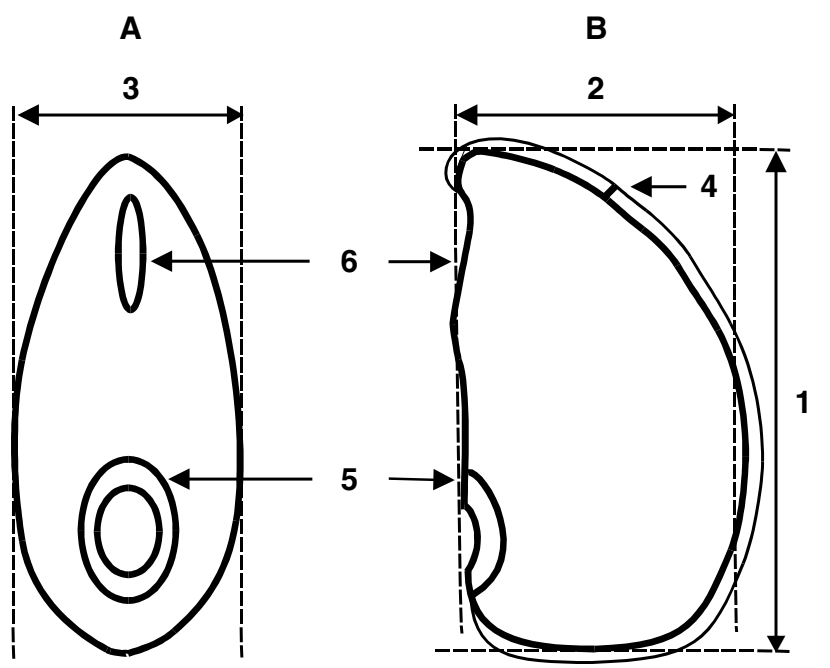

Fig. 1. Achene of Potentilla sp. [A] ventral and [B] lateral view; [1] length; [2] width; [3] thickness; [4] dorsal ridge; [5] aril around scare attachment; [6] style scare [after Anderberg (1994), modified]. limeter scale (exact to $0.05 \mathrm{~mm}$ ). At least 30 individual achenes were analyzed for each taxon.

For scanning electron microscopy (SEM) samples were mounted on metal stubs, sputtered with technical gold (Pelco S.C 6 coating system), examined and photographed using a Tesla BS 340 scanning electron microscope. Shape of achenes, dimensions of aril and ribs as well as the pattern of surface sculpture of the fruit wall were analyzed on 5 photographs for each taxon.

The obtained data were statistically analyzed by means of the Student'st test. A difference was considered statistically significant when $P<0.01$.

\section{RESULTS}

The achenes in Potentilla collina group are bilateral, their shapes vary from almost oval in $P$. leucopolitana and $P$. thyrsiflora var. isosepala (Fig. 2 and 7) to bean-like in $P$. wimanniana, $P$. silesiaca, $P$. collina and $P$. thyrsiflora (Figs 3-6).

Three types of achenes are distinguished: small, typical of $P$. leucopolitana and $P$. wimanniana, large, present in $P$. thyrsiflora var. isosepala and medium in size observed in the remaining taxa (Table 1).

Achene colour varies slightly from light brown in $P$. leucopolitana through nut-brown in $P$. collina, $P$. silesiaca, $P$. thyrsiflora and $P$. wimanniana to orange-brown in $P$. thyrsiflora var. isosepala (Table 1).

Scare attachment i.e. the point of achene attachment to the receptacle is surrounded by an aril slightly visible in $P$. collina and $P$ silesiaca or clearly - in P. leucopolitana, $P$. wimanniana, $P$. thyrsiflora and $P$. thyrsiflora var. isosepala with their respective widths being $10 \mu \mathrm{m}$ and 40 um (Table 2).

A clear dorsal ridge about $80-40 \mu \mathrm{m}$ wide and $20-40$ $\mu \mathrm{m}$ thick was present in achenes of $P$. leucopolitana (Fig. 2), P. wimanniana (Fig. 3), P. collina (Fig. 5) and P. thyrsiflora var. isosepala (Fig. 7) while an unclear one, about $40 \mu \mathrm{m}$ wide and $20 \mu \mathrm{m}$ thick was observed in $P$. silesiaca and $P$. thyrsiflora (Table 2).

Ribs seen at achene surfaces are brown in colour in $P$. collina and $P$. silesiaca or yellow in P. leucopolitana, $P$. thyrsiflora, $P$. thyrsiflora var. isosepala and $P$. wimanniana (Table 1). Distinct ribs, very sharp in shape were seen in achenes of $P$. silesiaca (Fig. 4A, B), P. collina (Fig. 5A, B) and $P$. thyrsiflora var. isosepala (Fig. 7A, B) or oval in shape - in P. leucopolitana (Fig. 2A, B), P. thyrsiflora (Fig. 6A, B) and $P$. wimanniana (Fig. 3A, B). Width of ribs varied from 10-20 $\mu \mathrm{m}$ in $P$. silesiaca through $40 \mu \mathrm{m}$ in $P$. collina up to $80 \mu \mathrm{m}$ in $P$. leucopolitana, $P$. thyrsiflora, $P$. thyrsiflora var. isosepala and $P$. wimanniana (Table 2). Similarly rib height was the lowest $(10 \mu \mathrm{m})$ in $P$. silesiaca while the largest $(40-60 \mu \mathrm{m})$ in $P$. leucopolitana, $P$. thyrsiflora, $P$. thyrsiflora var. isosepala and $P$. wimanniana (Table 2).

SEM analyses of the surface sculpture revealed two types of achenes:

I. With ruminate sculpture, characterized by oval ribs and epidermal cells partly destroyed and covered with numerous aggregates of some material (probably waxes etc.), various in shape and size. This type of achenes was typical for P. leucopolitana (Fig. 2), P. wimanniana (Fig. 3) and P. thyrsiflora (Fig. 6). 

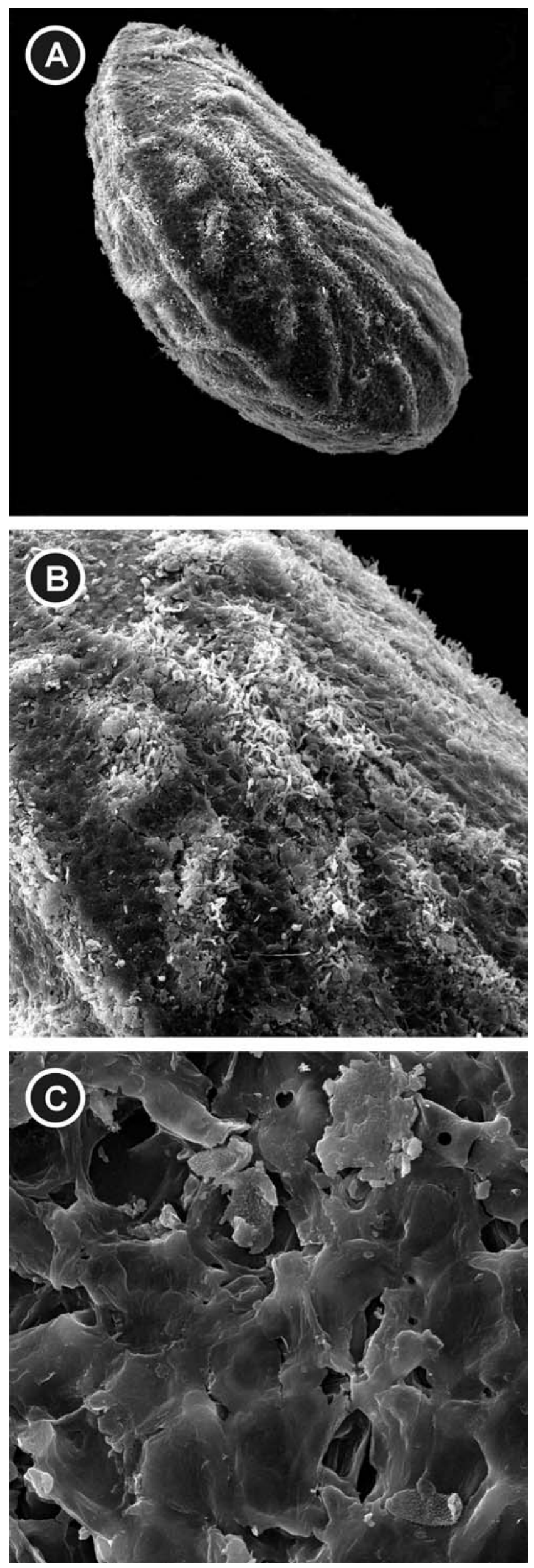

II. With ruminate-reticulate sculpture; among distinct and sharp ribs well preserved epidermal cells, hexagonal in shape were visible. Achenes of this type were characteristic of $P$. silesiaca (Fig. 4), P. collina (Fig. 5) and P. thyrsiflora var. isosepala (Fig. 7).

\section{DISCUSSION}

Taxonomy of $P$. collina group treated as a collective species is controversial because of lack of criteria to evaluate the systematic position of the particular taxa. Moreover, the problem of their taxonomic rank and phylogenetic relationships is also not defined. Therefore, in $P$. collina group an extensive and complicated synonymy appeared in consequence of various systematic classifications (Wolf 1908; Hegi 1923; Szafer and Pawłowski 1955; Ball et al. 1968; Szafer et al. 1976; Kurtto et al. 2004) and classification of many taxa to a lower order and then permanent changes in their rank. For example, Wolf (1908) divided the species aggregate of $P$. collina (as Potentilla Subgrex Collinae) into 16 microspecies (of witch 11 in Europe), later Juzepczuk (1941) (as Potentilla subsect. Collinae) distinguished 6 microspecies. A similarly narrow concept of species was presented by Kurtto et al. 2004, according to whom $P$. collina s.l. consists of 13 separate species in the area of Europe.

Therefore, besides difficulties in taxonomy, plants of $P$. collina group were improperly classified or simply unnoticed. For example, $P$. thyrsiflora var. isosepala was described by Błocki (1896) as "P. isosepala Bł". Later Wolf (1908) on the basis of features such as large flowers, significantly larger and longer stem, its dense foliage, seven leaflets on basal leaves, pattern of leaf blade crenation Wolf (1908) classified this taxon as variety of $P$. thyrsiflora.

Our investigations of taxa from $P$. collina group revealed differences in colour and shape of achenes, as well as in their sizes. According to our measurements the lengths of achenes, 1.2-1.3 mm, were similar to those described by Soják (1995), although significantly differed from the results obtained by Andenberg (1994), 1.4-1.9 mm.

Scanning electron microscopic analysis of achenes from $P$. collina group allowed to distinguish new additional features such as aril, dorsal ridge and aril dimensions, useful in taxonomy of this difficult collective species. These features of achenes in addition to the anatomy of leaves (Kołodziejek and Gabara 2003) proved to be of high systematic importance in taxonomy of Potentilla species. On the other hand, contrary to our expectations the surface sculpture cannot be a good criterium in classification of taxa from $P$. collina group in achenes $P$. collina, $P$. silesiaca and $P$. thyrsiflora var. isosepala it was almost identical although different from that of $P$. leucopolitana, $P$. wimanniana and $P$. thyrsiflora.

Fig. 2-7. Surface sculpture of the achenes of $P$. collina group, at different magnifications $[\mathrm{A}] \times 500 ;[\mathrm{B}] \times 1000 ;[\mathrm{C}] \times 3000$. Arrow indicates dorsal ridge. Fig. 2. P. leucopolitana P.J. Müller; Fig. 3. P. wimanniana Günther and Schumme; Fig. 4. P. silesiaca Uechtr; Fig. 5. P. collina; Fig. 6. P. thyrsiflora Hülsen ex Zimmeter; Fig. 7. P. thyrsifora var. isosepala Th. W. Specimens used in the morphological treatment:

Fig. 2. P. leucopolitana - Kujawy-Pomorze prov., Maksymilianowo near Bydgoszcz $55^{\circ} 13^{\prime} \mathrm{N} / 17^{\circ} 58^{\prime} \mathrm{E}$, pine coniferous forest, 12.08 .2005 , J. Kołodziejek. 

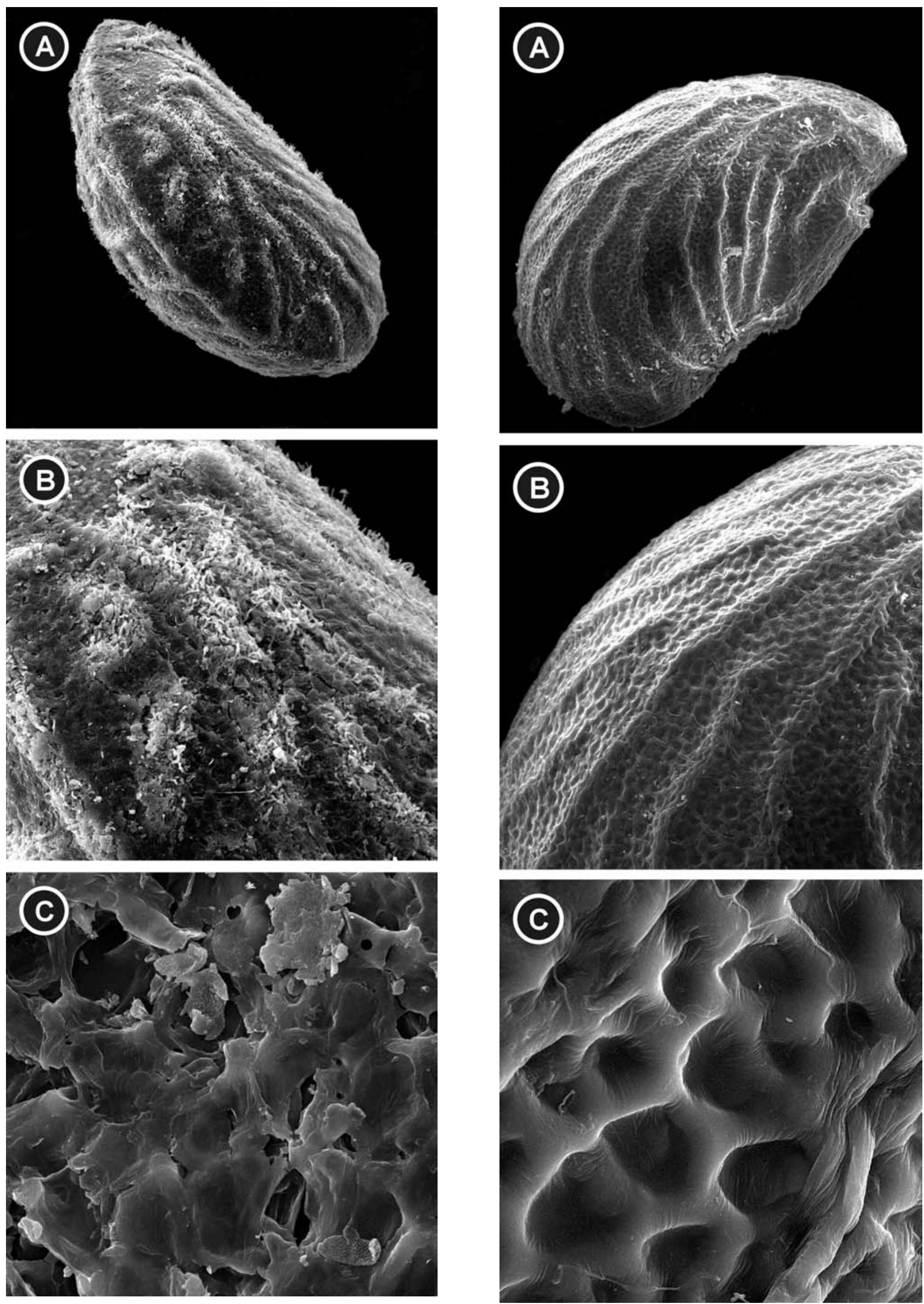

Fig. 3. P. wimanniana - Śląsk prov., Ogrodzieniec Podzamcze (region of Silesia-Cracow) $50^{\circ} 27^{\prime} \mathrm{N} / 19^{\circ} 33^{\prime} \mathrm{E}$, xerothermic grassland, 26.06.2004, J. Kołodziejek.

Fig. 4. P. silesiaca - Dolny Śląsk prov., Ostra Góra, between Miękinia and Mrozów (Breslau: Spitzberg, zwischen Nimkau und Nippern) loc. class., 28.06.1863, R. Uechtritz, (PRA). 

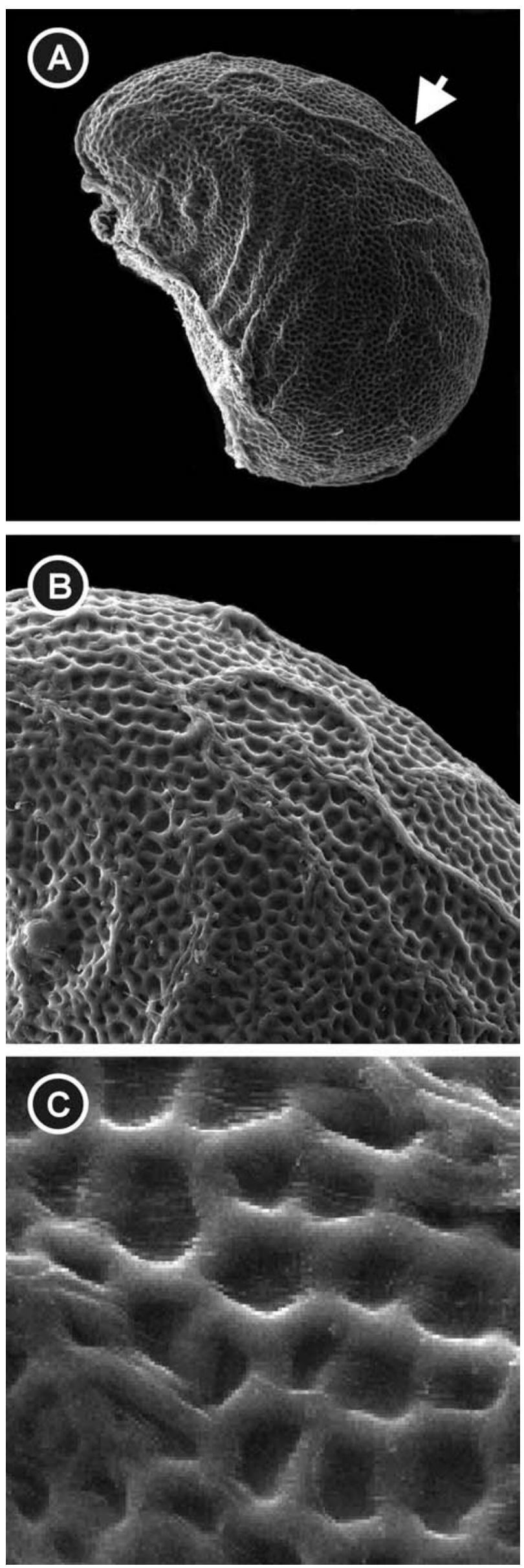

Fig. 5. P. collina s.s. - Śląsk prov., Kłobuck near Częstochowa $50^{\circ} 57^{\prime} \mathrm{N} / 19^{\circ} 59^{\prime} \mathrm{E}$, xerothermic grassland, 29.05.2004, J. Kołodziejek.
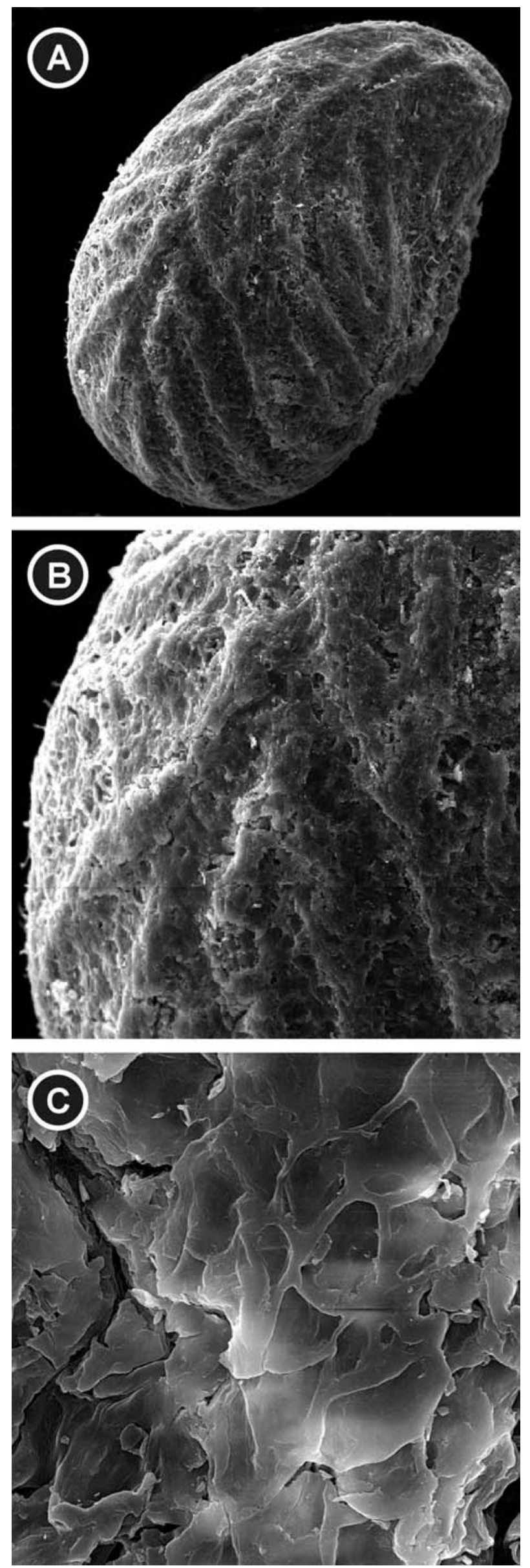

Fig. 6. P. thyrsiflora - Ślaask prov., Cisowa near Pilica $50^{\circ} 28^{\prime} \mathrm{N} / 19^{\circ} 43^{\prime} \mathrm{E}$ xerothermic grassland, 3.06.2004, J. Kołodziejek. 

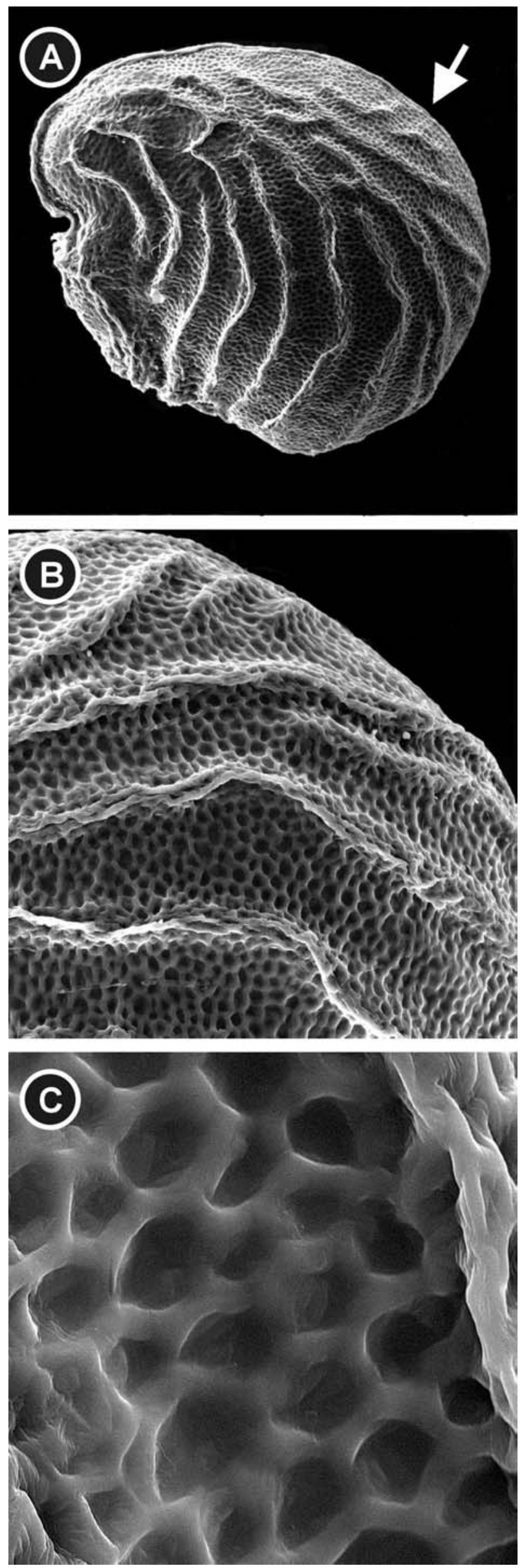

Fig. 7. P. thyrsiflora var. isosepala - Lwów prov. (Ukraine) - Kortumówka in collibus arenosis loc. class., 6.1896, B. Błocki, (BP 167343).
The results of the present paper indicate significant differences between $P$. thyrsiflora i $P$. thyrsiflora var. isosepala. Differences in colour, surface sculpture of achenes and in dorsal ridge dimensions do not support Wolf's (1908) classification of $P$. thyrsiflora as variety, on the contrary they indicate that this taxon should be identified as a species similar to Błocki's (1896) idea and termed $P$. isosepala.

Key to the species of genus Potentilla collina s.l. based on morphological characteristics of fruits.

1. Surface of achenes between ribs

with ruminate sculpture 2

$1 *$. Surface of achenes

with ruminate-reticulate sculpture 4

2. Colour light brown ........................... P. leucopolitana

2*. Colour nut-brown ..................................................... 3

3. Dorsal ridge clear, c. 80 um wide ....... P. wimanniana

$3 *$. Dorsal ridge unclear, c. $40 \mu \mathrm{m}$ wide ....... P. thyrsiflora

4. Colour orange-brown ...... P. thyrsiflora var. isosepala

4*. Colour nut-brown .................................................... 5

5. Dorsal ridge clear, ribs c. $40 \mu \mathrm{m}$ wide ......... P. collina

$5 *$. Dorsal ridge unclear,

ribs c. 10-20 $\mu \mathrm{m}$ wide ............................... P. silesiaca

\section{ACKNOWLEDGEMENTS}

We would like to thank the Curators of Herbaria for making available the material of Potentilla, and most of all Dr. Alexander Sennikov (V.L. Komarov Botanical Institute, Saint-Petersburg - LE), and Dr. Somlyay Lajos (Hungarian Natural History Museum in Budapest - BP) for lending the isotype Potentilla silesiaca Uechtr. and $P$. thyrsiflora var. isosepala Th. W. Finally, We would like to thank Dr. Krzysztof Polański (Institute of Physics, University of Łódź) for taking the photographs.

We would like to thank Professor Janina JakubowskaGabara (Department of Geobotany and Plant Ecology, University of Łódź), who made the critics of the manuscript.

Part of this work was supported by grant No. 2 P04F 040 26 from the Ministry of Education and Science (KBN).

\section{LITERATURE CITED}

ANDENBERG A.L. 1994. Atlas of seeds and small fruits of Northwest-European plant species with morphological descriptions. Resedaceae-Umbelliferae. Swed. Museum Natur. Hist., Stockholm 4: 28-31.

ASCHERSON P., GRAEBNER P. 1904-1905. Potentilla L. In: "Synopsis der mitteleuropäischen Flora". Ascherson P., Graebner P. (eds). Wilhelm Engelmann, Leipzig 6 (1): 664-872.

ASKER S. 1966. The occurrence of aberrants in some apomictic Potentilla argentea biotypes. Hereditas 56: 54-70.

ASKER S. 1970. Apomixis and sexuality on the Potentilla argentea complex II. Hereditas 66: 189-204.

ASKER S. 1985. Chromosome studies in Potentilla. Hereditas 102: 289-292.

ASKER S. 1986. Variation in some nordic Potentilla species. Acta Univ. Ups., Symb. Bot. Ups. 27: 199-205.

ASKER S., FRÖST S. 1970. The "Potentilla collina problem" a chemotaxonomic Approach. Hereditas 66: 49-70.

BALL P.W., PAWŁOWSKI B., WALTERS S.M. 1968. Potentilla L. In: "Flora Europaea". Tutin T.G. et al. (eds). Cambridge Univ. Press, Cambridge 2: 36-47. 
TABLE 1. Dimensions (in $\mathrm{mm}$ ) and colour of achenes from taxa of Potentilla collina group.

\begin{tabular}{|c|c|c|c|c|c|}
\hline \multirow{2}{*}{ Taxon } & \multirow{2}{*}{ Lengh } & \multirow{2}{*}{ Width } & \multirow{2}{*}{ Thicknes } & \multicolumn{2}{|c|}{ Colour } \\
\hline & & & & Achenes & Ribs \\
\hline P. leucopolitana & $1.16 \pm 0.02$ & $0.85 \pm 0.02$ & $0.64 \pm 0.01$ & Light brown & Yellow \\
\hline$P$. collina & $1.25 \pm 0.01$ & $0.96 \pm 0.01$ & $0.69 \pm 0.01$ & Nut-brown & Brown \\
\hline P. silesiaca & $1.30 \pm 0.01$ & $0.96 \pm 0.02$ & $0.72 \pm 0.01$ & Nut-brown & Brown \\
\hline P. thyrsiflora & $1.28 \pm 0.01$ & $0.96 \pm 0.02$ & $0.70 \pm 0.01$ & Nut-brown & Yellow \\
\hline P. thyrsiflora var. isosepala & $1.33 \pm 0.02$ & $0.99 \pm 0.02$ & $0.77 \pm 0.01$ & Orange-brown & Yellow \\
\hline P. wimanniana & $1.23 \pm 0.01$ & $0.89 \pm 0.01$ & $0.62 \pm 0.01$ & Nut-brown & Yellow \\
\hline
\end{tabular}

TABLE 2. Characteristic of achenes sculpture in taxa of Potentilla colina group.

\begin{tabular}{|c|c|c|c|c|c|c|c|c|}
\hline \multirow{3}{*}{ Taxon } & \multicolumn{2}{|c|}{ Aril } & \multicolumn{3}{|c|}{ Dorsal ridge } & \multirow{3}{*}{ Surface sculpture } & \multirow{2}{*}{\multicolumn{2}{|c|}{ Ribs $(\mu \mathrm{m})$}} \\
\hline & & \multirow{2}{*}{$\begin{array}{l}\text { Width } \\
(\mu \mathrm{m})\end{array}$} & & Width & Thickness & & & \\
\hline & & & & \multicolumn{2}{|c|}{$(\mu \mathrm{m})$} & & Width & Higth \\
\hline P. leucopolitana & Clear & 40 & Clear & 80 & $20-40$ & Ruminate covered with waxes? & 80 & $40-60$ \\
\hline$P$. collina & Unclear & 10 & Clear & 40 & 20 & Ruminate reticulate & 40 & 20 \\
\hline P. silesiaca & Unclear & 10 & Unclear & 40 & 20 & Ruminate reticulate & $10-20$ & 10 \\
\hline P. thyrsiflora & Clear & 40 & Unclear & 40 & 20 & Ruminate covered with waxes? & 80 & $40-60$ \\
\hline P. thyrsiflora var. isosepala & Clear & 40 & Clear & 80 & $20-40$ & Ruminate reticulate & 80 & $40-60$ \\
\hline P. wimanniana & Clear & 40 & Clear & 80 & $20-40$ & Ruminate covered with waxes? & 80 & $40-60$ \\
\hline
\end{tabular}

BERGGREN G. 1969. Atlas of seed. Swed. Natur. Sci. Res. Council, Stockholm 2: 1-68.

BŁOCKI B. 1896. Floristisches aus Galizien. Allg. Bot. Z. Syst., Karlsruhe 2: 3-6.

BORHIDI A., ISÉPY I. 1965. Taxa et combinationes novae generis Potentilla L. Acta Bot. Acad. Sci. Hung. 11: 297-302.

ERIKSSON T., DONOGHUE M.J., HINNS M.S. 1998. Phylogenetic analysis of Potentilla using DNA sequences of nuclear ribosomal internal trancribed spacers (ITS), and implications fort he classification of Rosoideae (Rosaceae). Pl. Syst. Evol. 211: 155-179.

FAGUNDEZ J., IZCO J. 2004. Seed morphology of Calluna Salisb. (Ericaeae). Acta Bot. Malacit. 29: 215-220.

GERSTBERGER P. 2002. 26. Potentilla L. In: "Gustav Hegi Illustrierte Flora von Mitteleuropa". Weber H.E. (ed.). Parey Buchverlag, Berlin 4 (2C): 109-205.

GREGOR T., ROLLIK J., WEISING K. 2003. RAPD-Untersuchungen und Chromosomenzählungen in der Potentilla-collina-Gruppe (Rosaceae). Ber. Bayer. Bot. Ges. 72: 159-167.

HEGI G. 1923. Potentilla L. Fingerkraut. In: "Gustav Hegi Illustrierte Flora von Mitteleuropa". Lehmans J.F. (ed.). J.F. Lehmann, München 4: 809-895.

JUZEPCZUK S. 1941. Potentilla L. In: "Flora URSS". Komarov V. (ed.). Moscow, Leningrad, 10: 68-223.

KARCZ J. 1996. Skaningowy mikroskop elektronowy w badaniach karpologicznych. Scanning electron microscope in carpological studies. Wiad. Bot. 40: 55-65. (in Polish with English summary)

KELLEY W.R. 1953. Study of seeds identification and seed germination of Potentilla app. and Veronica spp.. Cornell. Univ. Agric. Exp. Sta. Mem. 317: 3-31.

KOŁODZIEJEK J., GABARA B. 2003. Analiza morfologiczna i anatomiczna liści krajowych gatunków z grupy Potentilla collina s.l. (Rosaceae). Morphological and anatomical analysis of leaves in Polish species of the Potentilla collina group s.1. (Rosaceae). Genus Intern J. Inver. Taxon., (suppl.), pp. 27-36. (in Polish with English summary)

KURTTO A., LAMPINEN R., JUNIKKA L. (eds), 2004. 13. Rosaceae (Spiraea to Fragaria, excl. Rubus). In: "Atlas Florae
Europaeae. Distribution of Vascular Plants in Europe“. Comm. Map. Flora Eur. Soc. Biol. Fenn. Van., Helsinki, 13: 185-217.

LEHT M. 1990. The genus Potentilla L. In the Baltic republics. Pollen and seeds in SEM. Proc. Estonian Acad. Sci. Biol. 39: 28-33. (in Russian with English summary)

LIU J.Q., LIN S.J. 1999. Achene microstructure in Pycreus, Gahnia and Schoenus (Cyperaceae) from China and their taxonomic significance. J. Jap. Bot. 74: 150-160.

MACIEJEWSKA-RUTKOWSKA I., BEDNARZ L. 2004. SEM and stereoskope microscope observations on the sedes of the Polish species of the genus Sorbus L. (Rosaceae). Acta Soc. Bot. Pol. 73: 293-300.

MIREK Z., PIĘKOŚ-MIRKOWA H., ZAJĄC A., ZAJĄC M. 2002. Flowering plants and pteridophytes of Poland. A checklist. Krytyczna lista roślin naczyniowych Polski. Wyd. Instytutu Botaniki im. W. Szafera Polskiej Akademii Nauk, Kraków. Ser.: Różnorodność biologiczna Polski. Vol. 1: 129-130.

MÜNTZING A. 1928. Pseudogamie in der Gattung Potentilla. Hereditas 11: 267-283.

MÜNTZING A. 1931. Note on the cytology of some apomictic Potentilla-species. Hereditas, 15: 166-178.

MÜNTZING A. 1958. Further Studies on Intraspecific Polyploidy in Potentilla argentea (coll). Bot. Not. 111: 209-227.

ÖZCAN T. 2004. Analysis of the fruit surface in Bupleurum L. (Umbelliferae) with SEM. Plant. Syst. Evol. 247: 61-74.

SOJÁK J. 1995. Potentilla. In: "Flora of the Czech Republic". Slavik B. (ed.). Academia, Praha 4: 283-314. (in Czech)

STACE C.A. 1989. Plant taxonomy and biosystematics. E. Arnold Publ., Cambridge (Polish translation: Stace A. 1993. Taksonomia roślin i biosystematyka. PWN, Warszawa), pp. 340.

SZAFER W., PAWŁOWSKI B. 1955. Potentilla L. In: "Flora Polska. Rośliny naczyniowe Polski i ziem ościennych". Szafer W., Pawłowski B. (eds). PWN, Warszawa, 7: 96-143.

SZAFER W., KULCZYŃSKI S., PAWŁOWSKI B. 1976. Potentilla L. In: "Rośliny polskie. Opisy i klucze do oznaczania wszystkich gatunków roślin naczyniowych rosnących w Polsce bądź dziko, bądź też zdziczałych lub częściej hodowanych". Szafer W. et al. (eds). PWN, Warszawa, pp. 312-320. (in Polish) 
WOLF T. 1901. Potentillen-Studien I. Die sächsischsen Potentillen und ihre Verbreitung besonders im Elbhügellande mit Ausblicken auf die moderne Potentillenforschung. Wilhelm Paeusch, Dresden, pp. 31.

WOLF T. 1903. Potentillen-Studien II. Die Potentillen Tirols. Wilhelm Paeusch, Dresden, pp. 72.

WOLF T. 1908. Monographiae der Gattung Potentilla L. Biblioth. Bot. 16: 1-714
ZAJĄC A., ZAJĄC M. (eds), 2001. Atlas rozmieszczenia roślin naczyniowych w Polsce. Distribution Atlas of Vascular Plants in Poland. Nakładem Pracowni Chorologii Komputerowej Instytutu Botaniki Uniwersytetu Jagiellońskiego, Kraków, pp. 714. (in Polish with English summary) 